\title{
A STUDY ON THE POPULARITY OF HANDMADE PRODUCTS AMONG CONSUMERS
}

\author{
Erzsébet Major $^{1^{*}}$, Irén Köszegi ${ }^{2}$, Esmeralda Kadëna ${ }^{3,4}$ \\ 1student, Faculty of Horticulture and Rural Development, John von Neumann University, Hungary \\ 2Department of Agroecomony and Rural Development, Faculty of Horticulture and Rural Development, John \\ von Neumann University, Hungary \\ 3Universiteti Europian I Tiranës, Albania \\ 4Obuda University, Doctoral School on Safety and Security Sciences, Hungary \\ https://doi.org/10.47833/2020.3.AGR.002
}

\section{Keywords:}

handmade products

primary research

\section{Article history:}

Received 12 Nov 2020

Revised 20 Nov 2020

Accepted 25 Nov 2020

\begin{abstract}
The focus of this study was to examine the popularity of handmade products among consumers through a survey. We shed light on the effect of the socio-demographic factors such as agender identity, age, education, and income level,on consumer behavior (frequency of purchase, purchase considerations, most popular place of purchase), and consumer demand. The results point out that handmade products are becoming increasingly popular. The surveyed consumers chose high-quality food, which can be beneficial for the manufacturers of handmade products. Hence, we suggest that providing local services and products can be an ideal opportunity to generate income in rural regions. Since only 51 people were surveyed, we are aware that our work cannot be representative, and further data collection and analysisare planned for future work.
\end{abstract}

\section{Introduction}

Nowadays, the revolutionary technologyhas reduced the human role in the production processes and not only[1]. Since the Industrial Revolution, the human activity has been limited to the production process[2], [3].In many cases, people are not involved at all during the whole production process[4]. Since machines are supposed to be consistent, precise, quick, and to provide high-quality products, they have brought many benefits for the world[4], [5]. Nonetheless, the shift from handmade products to the mechanization of production has some drawbacks. For instance, Marx disagreed with the existing production mode where humans and machines engage in the same continuous actions that make only one step in a multi-step production process and the end, that provide little peculiar satisfaction[6].This production mode is in contrast with the handmade process where: one artisan is responsible for controlling and executing the whole production, artisans work and invest even years in mastering their craft, and in addition, they invest from their selves which leads to satisfaction from the production process and their labor time.

Handmade products are made by traditional equipment and technology; the substances used are natural, and the techniques are manual. Thus, handmade food products are considered more valuable than processed ones. They do not contain preservatives and harmful substances for the human body. In the systematic review of Romána, Sánchez-Siles, and Siegrist, it was shown that for the majority of consumers, food naturalness is very important [7]. In a study conducted among 30,000 consumers in 60 countries, it was revealed that the most significant features of food are freshness, naturalness, and minimal processing[8].Consumers seek such food, so they can be aware of what they consume; most of the reasons were attributed to health benefits. Ingredients of

\footnotetext{
* Corresponding author, Email: major.erzsebet1976@gmail.com
} 
handmade food are time-honored plants, animals, and herbs of nature whose compounds are valuable in the aspect of a healthy diet; thus, they can have an essential role in health care.

The phrase "handmade food" appears in various literature, but its definition remains unclear. Conventional methods do not produce handmade food; instead, they are similar to traditional and regional food products.

\section{Literature review}

\subsection{Definition of crafts and handmade products}

According to the Hungarian Interpretive Handbook, the concept of crafts stands for the industrial production carried out by unique processes and simple tools [9]. In literature, crafts aresomewhat circumscribed than have an exact definition. Based on the content of the various circumscription, one can call crafts as the process of transforming raw materials with human power and hand tools. The products created in this way are called handicrafts. The term "craft" is gaining more and more popularity among the other products in supermarkets, bars, and restaurants, and it is being used more by sellers to differentiate their products. Although, in 2018, the School of Artisan Food indicated that there could not find a single definition of artisan food.

The origins of handmade products date back to the Middle Ages. However, the concept of handmade products significantly changed during the 19th and 20th centuries. In the traditional peasant culture, handicrafts included the activities of home craftsmen, artisans, and the objects they created. In today's terminology, the concept of crafts consists of the creation of objects from artisanal work to artistic design, contrary to mechanized factory production. The artisans see through the whole process of production and can carry out any of its movements. Contrary to the machine work and mass production, the production process of handicrafts relates to the expertise and manual shaping where the typical output is the production of small series of goods[10].

Currently, consumers prefermore and moretraditional and manually produced goodies, so manufacturers increasingly apply conventional technologies and sell their products as handicrafts. Howard called this phenomenon "craftwashing" [11]; industrial firms use deceptive marketing practices in the food and beverage sector to attract more consumers and increase their sales by "naming" their new products as hand-crafts. Oftentimes, we can see that the "hand-crafted" is only a "crafty-marketing" [12].

Therefore, nowadays, it is not easy to define the term of craft and also to choose a method for doing so in each production sector.

\subsection{Role of handmade products in rural development}

Within the development program of the National Rural Strategy, there are many opportunities for micro-regions to use their traditional values as a force for rural development. It can retain and create jobs, which is also crucial because crafts today provide a livelihood for only a small percentage of the population. Few young people choose these crafts, training is unresolved, so artisan society is aging. To avoid aging, the handicraft program takes part in the National Rural Strategy, in which strategic directions and tasks were formulated:

- Cooperation of craftsmen, and their motivation for market access, e.g., craft fairs, craft shows, local markets.

- It is essential to link handicrafts with local agricultural and horticultural production, local manufacturers, rural tourism, local hospitality and local services. That by-product from production is processed locally, directly, so the higher value-added product is produced and sold locally.

- Encouragement and support of the operation of county and local folk art associations and creative communities, as well as the activities of public cultural institutions in this field.

- Encouraging the opening of craft shops in villages or micro-regions,the establishment of craft creative houses, and the development of the existing ones as well [13]. 
Providing local products and services is a viable method for generating incomes in rural regions. As a first step, we should encourage the appreciation of local products so we can give them space in the domestic market. Traditional local handmade products are made locally and not imported from abroad.Their transport distance does not exceed $50 \mathrm{~km}$, except for online sales. The handicraft is not a mass product but a local specialty. Based on these, emphasizes that local products are important tools for job creation, preservation and maintenance of traditions, creation, and development of the livable countryside[14, 16]. A common feature of local products is that their manufacturers use the knowledge gained over several generations. The production of local, traditional products is conducive to job creation and job retention in rural regions. They significantly contribute to the maintenance, preservation, and rebirth of traditions, and the creation and maintenance of a livable countrysideas well.

One of the main aspects in the production of handmade food is the creation of sustainability. From the 1990s, a new grassroots movement began in the world, the ecovillage concept, which is an integral part of the United Nations Environment Programme's (UNEP) theme of Promoting Sustainable Urban Development[15]. Ecological, economic, political, and social sustainability must be ensured for complete success. Handmade food production fits organically into this system.

Today people's demand for healthy food increases. Besides, consumers' demand continually changes. Global food chains have dominated in recent decades, which have made it difficult to connect the manufacturer and the consumer. In most cases, the goods travel up to thousands of kilometers before they reach the shelves. Today, however, wealthier shoppers are increasingly motivated by the experience of personality and trust when it comes to food. Personal presence creates a new kind of sense of community that leads to a connection between manufacturers and consumers. The emphasis on direct sales means the appreciation of local knowledge and experience where besides, local farmers can expect additional incomes.

\section{Material and methods}

To collect the primary data, we used anonymous survey. The generated link was sent via Internet platforms, and we also used the printed versions. The questionnaire was designed in a way that would be easier for the respondents to answer. It was developed around the idea of exploring the popularity of handmade products among consumers. The survey was carried out from June 2019 to September 2019.

Regarding the structure, it contained a section with demographics questions that collected general data and information about gender, age, education level, income level, job position/level, place of residence, and marital status. In the next part, the focus was on specific questions related to handmade products and consumers' behavior. The total of respondents was 51; hence, the survey is not considered as a representative, and further work is suggested.

\section{Results}

In the first question of the survey, we gave the respondents the definition of handmade products. The respondents had to answer about what kind of handmade products have they already bought? Most of the respondents (21 persons) bought products from the category of syrups and jams. This was followed by the cosmetics' category (14 persons) and dairy products ( 8 persons). Respondents did not really buy handmade oils and leather goods (Figure 1). 


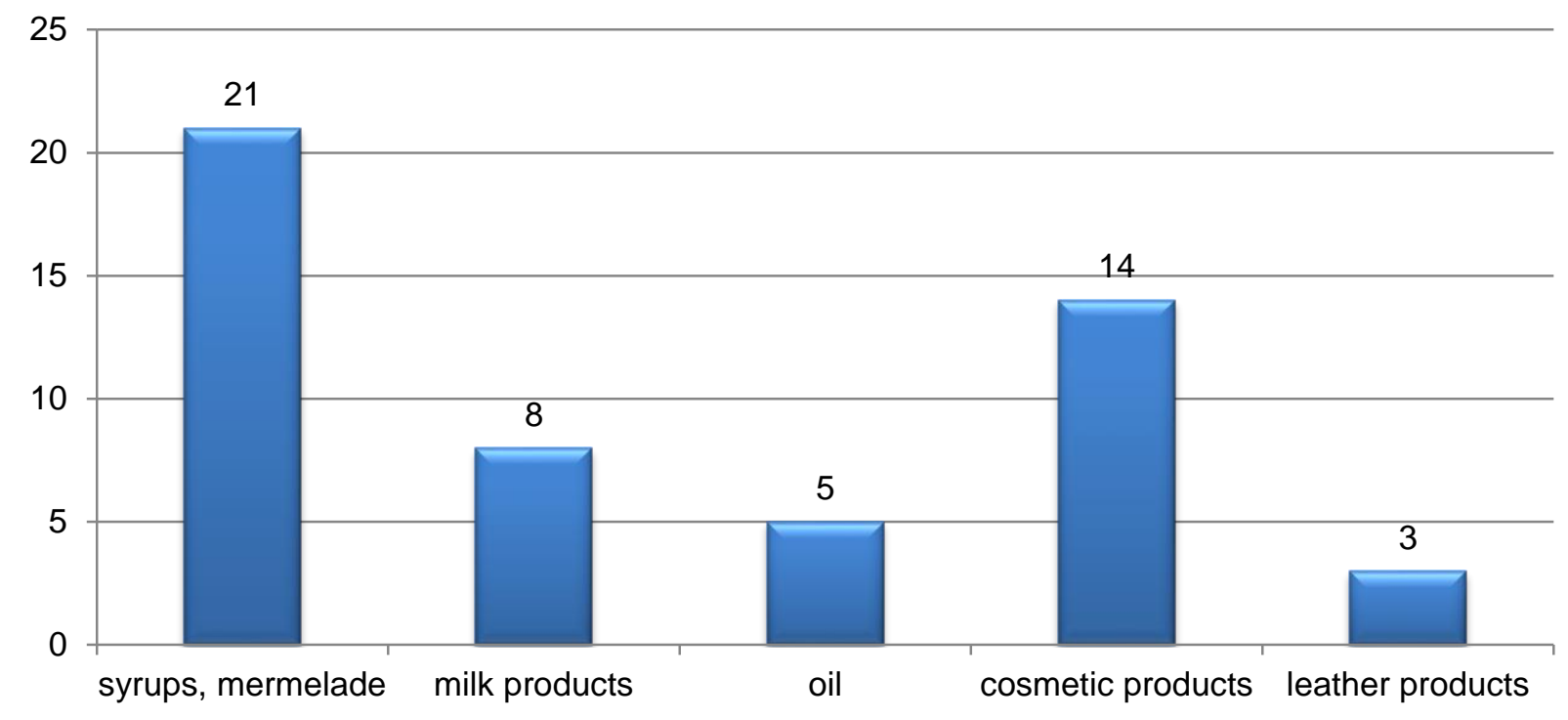

Figure1:Breakdown of purchases of handicraft products by product type (persons) $\mathrm{N}=\mathbf{5 1}$ Source: Own editing based on own research (2019)

In general, respondents like handmade products. Results showed that most of them are women, work as employees, and live in cities. As regards the age groups, 14-30 and 31-45 age groups responded in equal proportions(Figure 2).

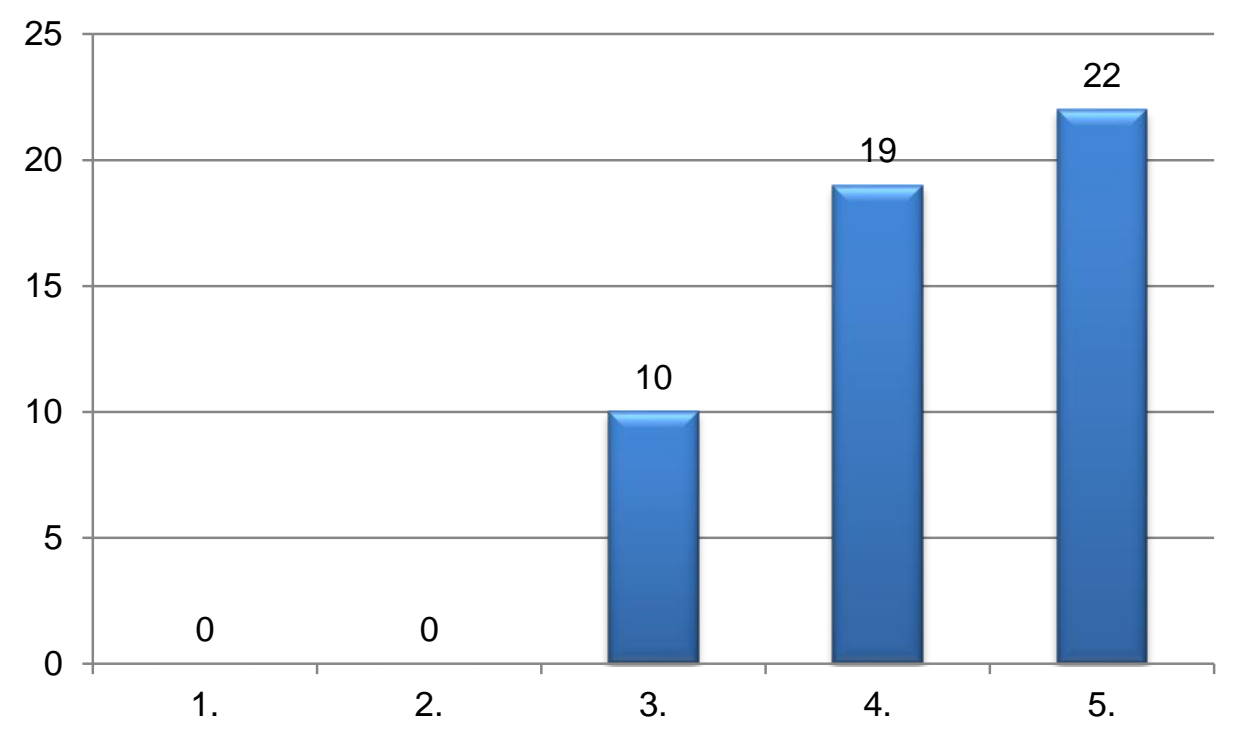

Figure2: Popularity of handmade products (persons) $\mathrm{N}=\mathbf{5 1}$

Source: Own editing based on own research (2019)

Nineteen respondents usually buy handmade products at fairs and festivals. Twelve of them buy products at markets. The fact contributes to the result that most of the respondents are in the 1430 age group. This age group might visit festivals mostly. Purchasing at the market is the most popular among 31-45 years older adults(Figure 3 ). 


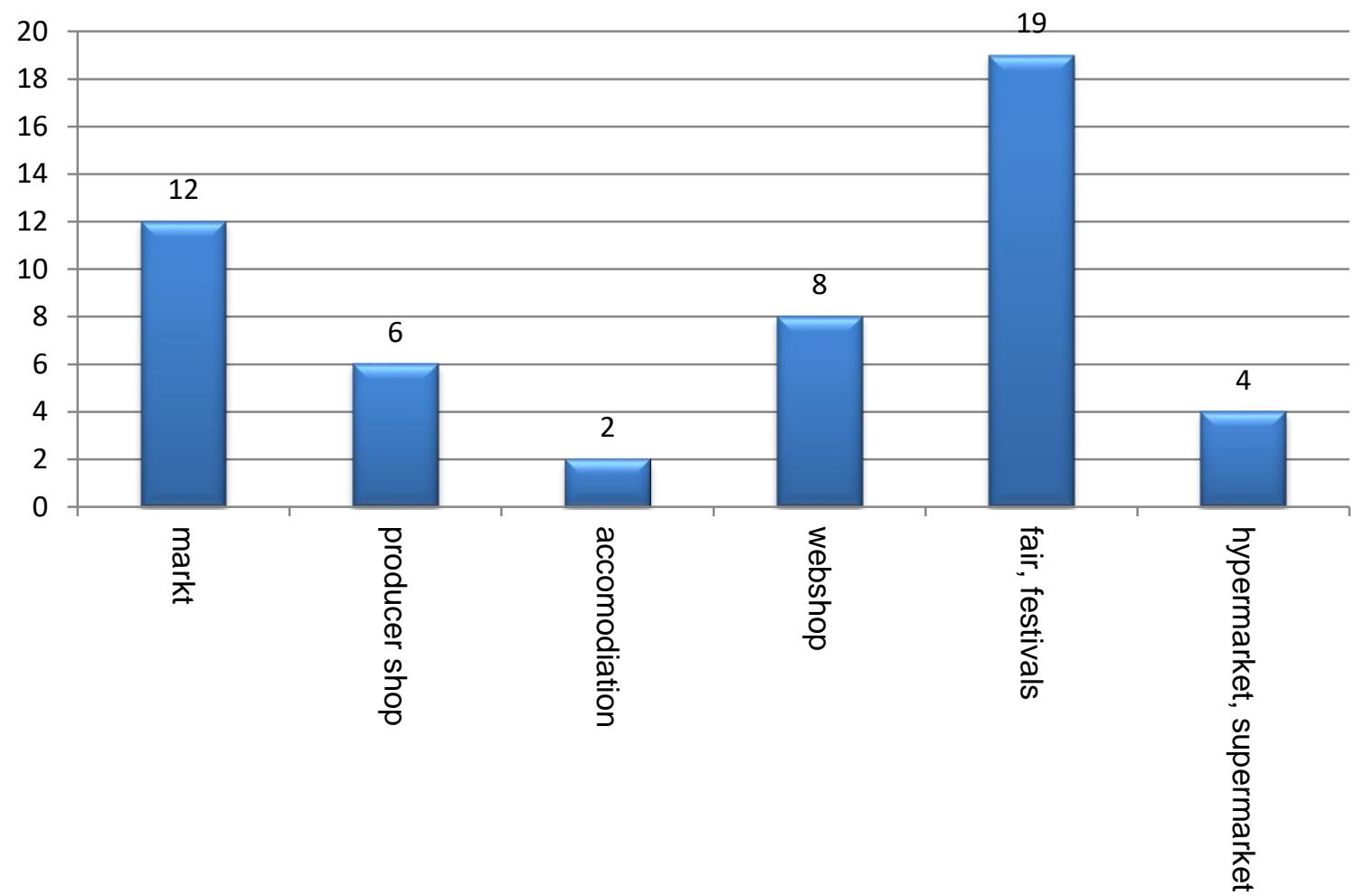

Figure3: Distribution of place of purchase (persons) $\mathrm{N}=51$

Source: Own editing based on own research (2019)

More than half of the respondents (32 persons) buy handmade products less frequently than monthly. Seventeen respondents buy handmade products monthly. Only four respondents buy handmade products more than once per month. Results showed that handmade products are popular among consumers, although they are buying these products occasionally. The frequency of purchasing is in connection with the respondents' monthly income. Moreover, the festivals are seasonal; they are organized mostly in spring and summer(Figure 4).

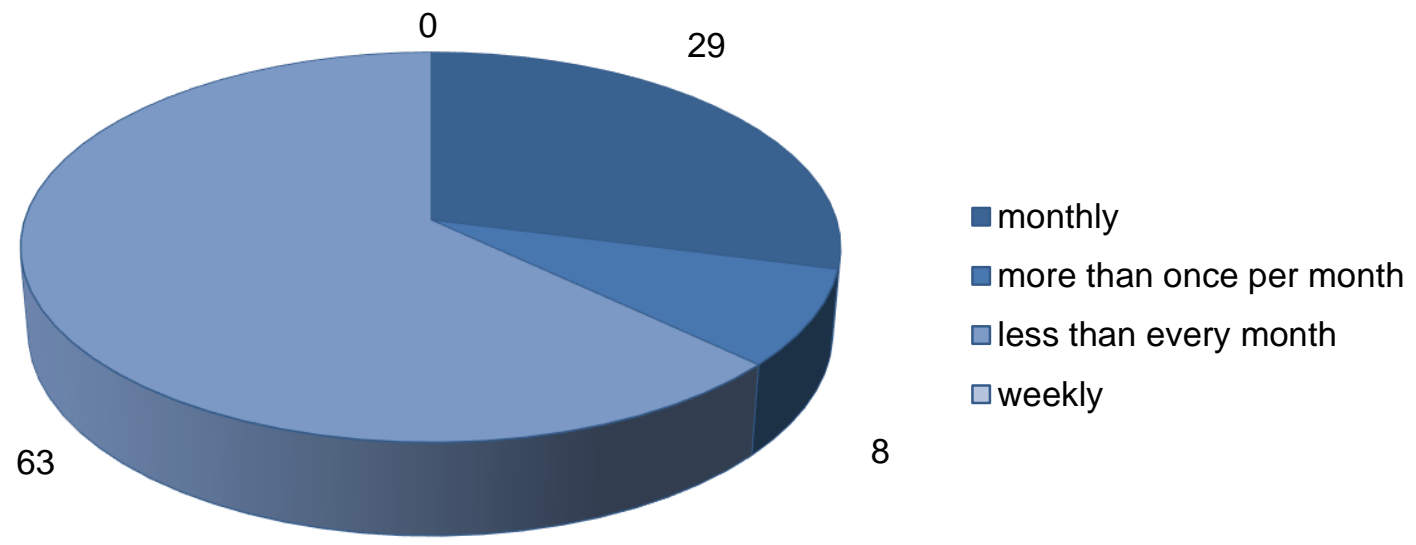

Figure4: Frequency of purchasing the handmade product (\%) $\mathbf{N}=51$

Source: Own editing based on own research (2019) 
As regards the most important aspect during purchasing, 25 respondents choose high quality, ten respondents choose the national origin, and nine respondents choose a healthy diet. According to the respondents, knowing the farmer and the price are not such important aspects during purchasing(Figure 5).

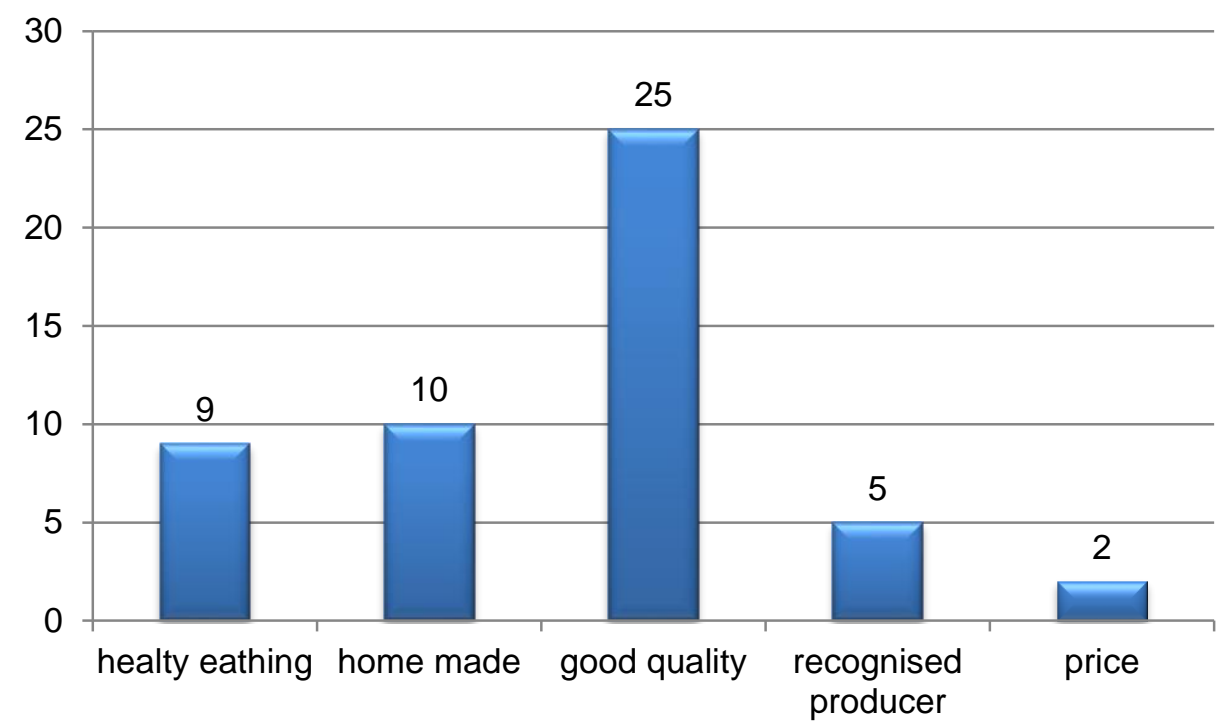

Figure5: Considerations of purchasing handmade products (persons) $\mathbf{N}=\mathbf{5 1}$

Source: Own editing based on own research (2019)

Respondents who buy handmade products are willing to pay only $10-25 \%$ more money for handmade products compared to mass products. Most of the respondents are women who live in cities and are in the 14-30 age group, followed by the 31-45 age group follows them. Nobody is willing to pay $50 \%$ more money for handmade products(Figure 6 ).

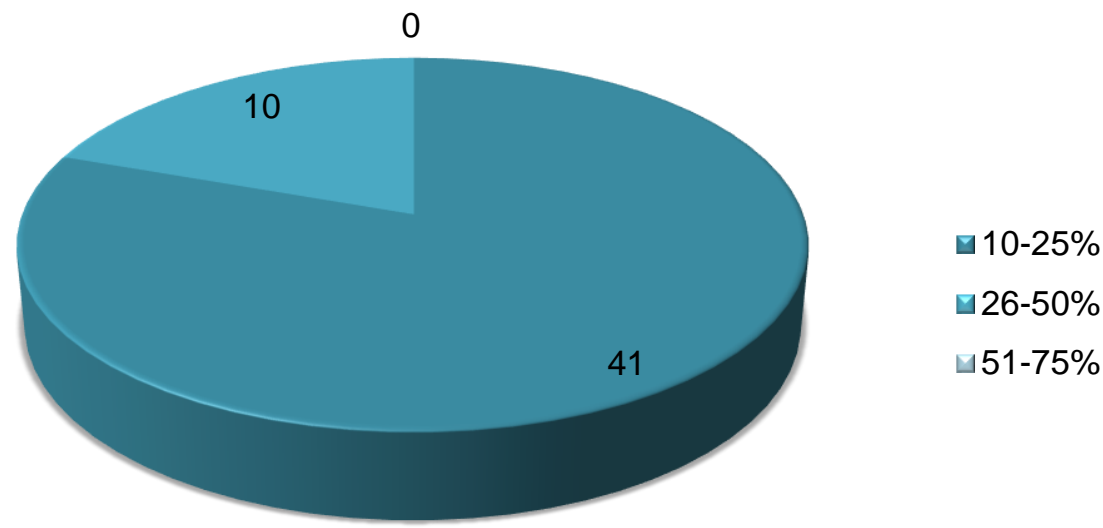

Figure6: Distribution of consumers who is willing to pay more for handmade products (persons) $\mathrm{N}=51$

Source: Own editing based on own research (2019)

According to $57 \%$ of the respondents, the origin should be indicated on the label(Figure 7 ). 


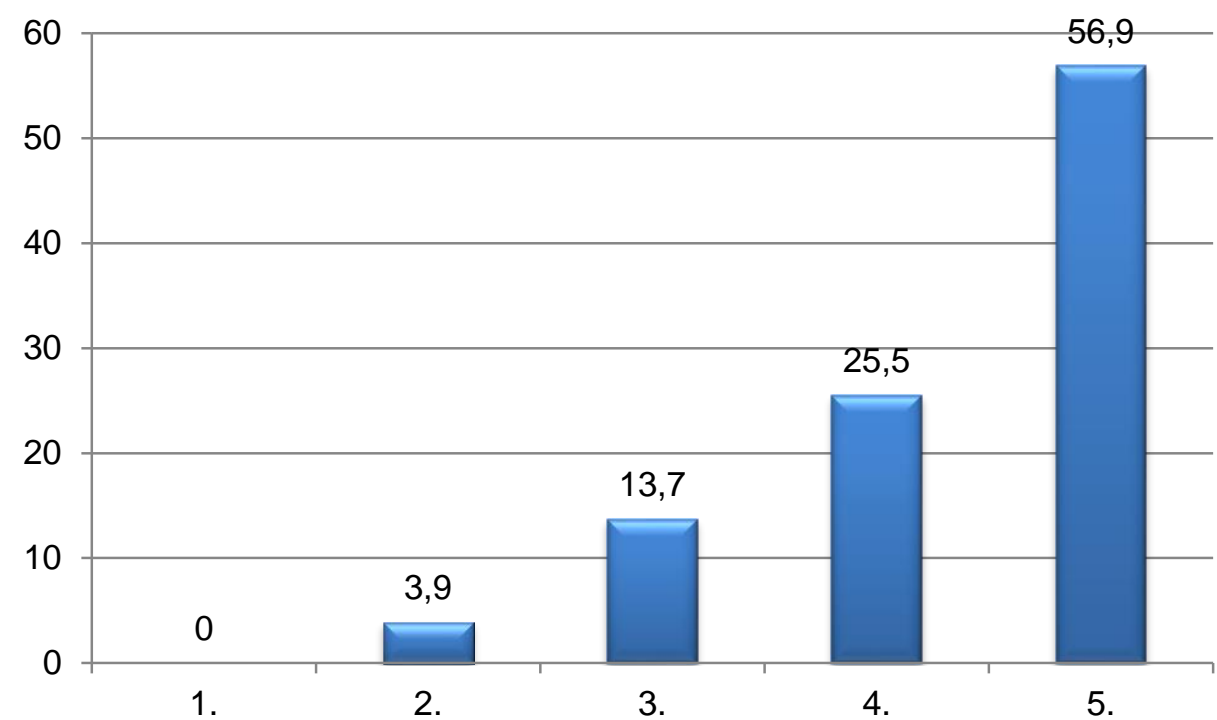

Figure7: Indication of handmade products' origin on the label (\%) $\mathbf{N}=51$

Source: Own editing based on own research (2019)

Respondents prefer to buy marmalade the most;fruit juices follow it. Many people tend to purchase syrups and dried fruits, too(Figure 8).

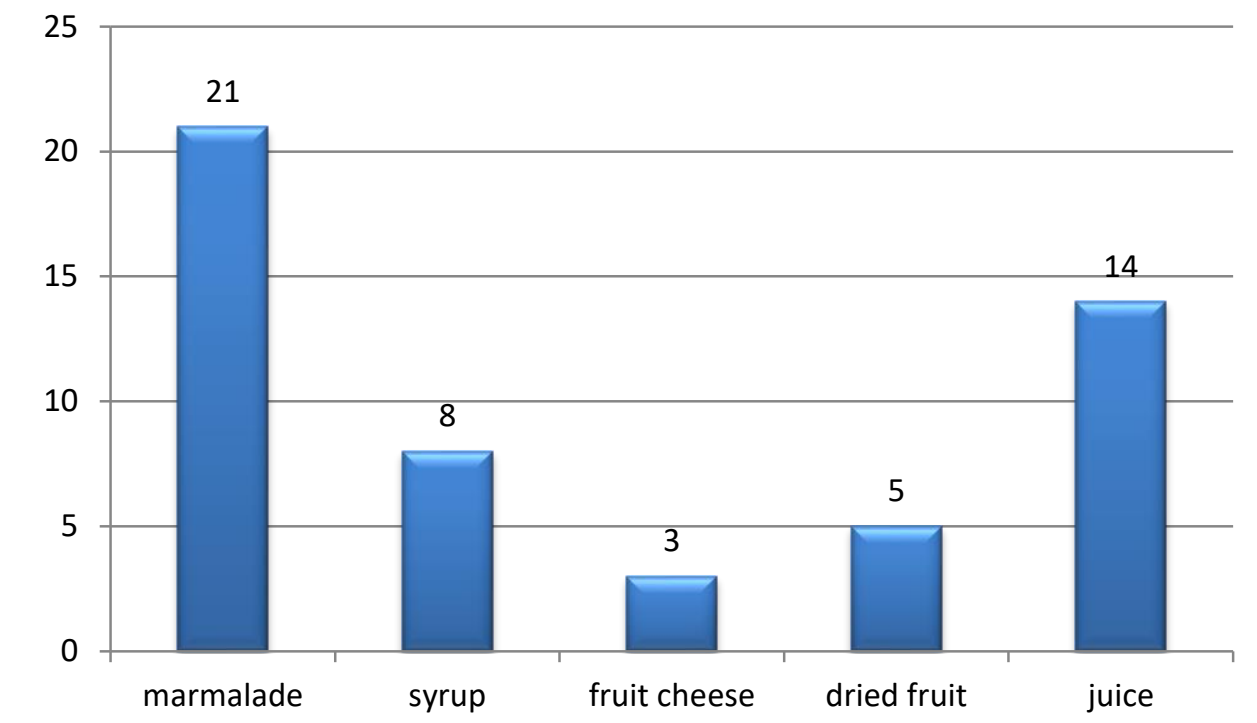

18: Type of fruit products by the frequency of purchase (persons) $\mathrm{N}=51$

Source: Own editing based on own research (2019)

There is a survey of 51 respondents ( 37 women, 14 men).

Most of the respondents (24 persons) are in the 14-30 age group, and 18 persons are in the 31-45 age group.

As regards the highest education, 15 respondents have a high school certificate, 12 respondents have a university degree, and nine respondents have a college degree. Five respondents have elementary education.

As regards the job, 23 respondents are students, 12 respondents are employees, nine respondents are mid-level managers, four respondents are high-level managers, and two respondents are retired persons. 
Forty-one respondents live in the city, seven persons live in town, and three persons live in a village. Regarding marital status, 19-19 respondents have families and relationships, and 13 persons are single.

Results show that young women and people who live in the city and have high school certificate pay the most attention to handmade products.

\section{Conclusions, suggestions}

This article began by introducing the differences between handmade and mechanized products. We highlighted the importance and benefits of handmade products to consumers. Then, some definitions regarding crafts and handmade products were given. Due to different sectors and deceptive marketing methods in the world we live in, it is hard to have a comprehensive definition. Also, we explain the crucial role of such products and their contribution to rural development.

The conducted survey showed that handmade products gain more and more popular among consumers.Consumers choose high-quality food, which can be beneficial for manufacturers of handmade products. The study found that most consumers of handmade food are young women with higher education that live in cities. Respondents think that it is essential that handmade food has high quality, national origin, and can be a part of a healthy diet. Respondents buy handmade products, particularly at markets, fairs, and festivals. This fact can be beneficial for family farms because they can sell their products the most easily at farmers' markets and local festivals. Handmade products' prices make these products disadvantageous compared to mass products because most of the respondents are willing to pay minimally more money for handmade products compared to mass products.

As it was shown, the number of respondents is not representative, and this study should be viewed in light of its limitations. However, the results can be considered as initial findings and motivation for future work.

\section{Acknowledgment}

Thank you for the support of the research carried out in the framework of the EFOP-3.6.2-162017-00012 „Developing a functional, healthy and safe food product chain model from field to table in a thematic research network". The project is funded by the Hungarian State and the European Union, co-financed by the European Social Fund, and is part of the Széchenyi 2020 program.

\section{References}

[1] E. Brynjolfsson and A. Mcafee, Race Against the Machine. Lexington, Massachusetts: Digital Frontier Press, 2011.

[2] H. Holtermann, "Hechter, Michael \& Christine Horne (2009) Theories of Social Order: A Reader (2nd edn). Stanford, CA: Stanford University Press. 350 pp. ISBN 9780804758727," J. Peace Res., vol. 47, no. 4, p. 514, Jul. 2010.

[3] M. Munger, "Division of Labor, Part 1," Adam Smith Works, 2019. [Online]. Available: https://www.adamsmithworks.org/life_times/division-of-labor-part-1. [Accessed: 14-Sep-2020].

[4] J. Markoff, "New Wave of Deft Robots Is Changing Global Industry," The New York Times, 2012. [Online] Available: https://www.nytimes.com/2012/08/19/business/new-wave-of-adept-robots-is-changing-globalindustry.html. [Accessed: 14-Sep-2020].

[5] M. Liebl and T. Roy, "Handmade in India: Preliminary Analysis of Crafts Producers and Crafts Production," Econ. Polit. Wkly., vol. 38, no. 51/52, pp. 5366-5376, Sep. 2003.

[6] A. Blunden, "Marx. Economic and Philosophic Manuscripts of 1844," marxists.org, 2000.

[7] S. Román, L. M. Sánchez-Siles, and M. Siegrist, "The importance of food naturalness for consumers: Results of a systematic review," Trends Food Sci. Technol., vol. 67, pp. 44-57, 2017.

[8] The Nielsen Company, "The Nielsen Global Health \& Wellness Survey - We are what we eat," 2015. 
[9] P. Juhász, "Leckéink a mezőgazdaság új rendje érdekében (Tanulmányok)," Szociológiai Szle., no. 2, pp. 33-46, 1998.

[10] K. Benedek, “'Kézművesség, népi kézművesség' In Mesterségem címere - a használható hagyomány, a népi kézmüvesség stratégiája," 2013.

[11] P. H. Howard, "Craftwashing in the U.S. Beer Industry," Beverges, vol. 4, no. 1, pp. 1-13, 2018.

[12] K. Wilson, "When 'hand crafted' is really just crafty marketing," The Conversation, 2015. [Online]. Available: https://theconversation.com/when-hand-crafted-is-really-just-crafty-marketing-47749. [Accessed: 14-Sep-2020].

[13] Vidékfejlesztési Minisztérium, “Nemzeti Vidékstratégia 2012 - 2020," 2020.

[14] T. Gonda, "A helyi termék turisztikai hasznosítása - a vidékfejlesztés új lehetősége," A falu, vol. 29, no. 1, pp. 17-23, 2014.

[15] UNEP, “UNEP - UN Environment Programme.” [Online]. Available: https://www.unep.org/. [Accessed: 14-Sep2020].

[16] Raffay Z.- Gonda T. Az akadálymentes turizmus innovatív jó gyakorlata Modern Geográfia 2020 :4 pp. 1-14. DOI 10.15170/MG.2020.15.04.01 